\title{
PELAKSANAAN ASURANSI TERHADAP DEBITUR SECARA TANGGUNG RENTENG DIHUBUNGKAN DENGAN PASAL 1278 KUH PERDATA
}

\author{
Oleh : ALIS YULIA, S.H., M.H. ${ }^{*}$
}

\begin{abstract}
Based on the facts and realities that occur in the field about the kinds of coverage and the level of risk in the implementation of insurance against the debtor. Joint responsibility not fully applicable because it is tied to an insurance agreement is just the first of existing borrowers and Letter of Acknowledgement of Debt, while consumer credit as the bear the risk as a borrower is not necessarily the first.
\end{abstract}

\begin{abstract}
ABSTRAK
Berdasarkan fakta-fakta dan kenyataan-kenyataan yang terjadi di lapangan tentang macam-macam pertanggungan dan tingkat resikonya dalam pelaksanaan asuransi terhadap debitur. Secara tanggung renteng tidak sepenuhnya bisa diterapkan karena terikat dengan perjanjian asuransi hanyalah debitur pertama yang ada dan Surat Pengakuan Hutang, sedangkan pemakai kreditnya sebagai yang menanggung resiko belum tentu sebagai peminjam pertama.
\end{abstract}

\footnotetext{
*) Dosen Fakultas Hukum Universitas Galuh
} 


\section{Pendahuluan}

Semakin berkembangnya kehidupan manusia, semakin berkembang pula kebutuhan hidup yang harus dipenuhi oleh seseorang. Perkembangan kehidupan manusia semakin modern, ditandai dengan berkembangnya dunia perekonomian tersebut, disisi lain ada suatu resiko atau peristiwa tidak tentu, yang tanpa dapat diduga sebelumnya, misalnya resiko bencana alam, kematian dan hal-hal di luar perhitungan manusia selalu akan datang setiap saat tanpa pernah memberikan tanda-tanda sebelumnya.

Salah satu tindakan yang diambil untuk pengaturan ekonomi dan keuntungan sebagai akibat dari suatu peristiwa tidak tentu tersebut adalah dengan adanya pertanggungan atau asuransi. Saat ini Asuransi telah memainkan peranan penting dalam pertumbuhan industri maupun perekonomian.

Asuransi atau pertanggungan di Indonesia telah mengalami kemajuan yang sangat pesat, hal ini dilihat semakin banyaknya perusahaan-perusahaan asuransi yang muncul, sehingga dengan demikian perlu adanya suatu pengaturan atau ketentuan-ketentuan yang jelas sehingga perusahaanperusahaan asuransi dapat bertahan lama.

Timbulnya asuransi didasari pada terpikirnya suatu prinsip ilmiah sosial yang berguna, dimana dinyatakan bahwa dengan menanamkan sejumlah modal kecil industri dapat bebas dari kerugian finansial yang mungkin terjadi akibat suatu peristiwa yang tidak tentu, sehingga banyak orang yang menanamkan modalnya kalau sewaktu-waktu mendapat musibah yang dapat merugikan dirinya, maka ia akan mendapat penggantian kerugian itu dengan sejumlah apa yang diperjanjikan.

Perjanjian asuransi atau pertanggungan di dalam pengertian yang murni harus mengandung suatu tujuan bahwa kerugian yang sungguh-sungguh diderita oleh pihak tertanggung akan diganti oleh pihak penanggung, oleh karenanya terhadap suatu penggantian kerugian, maka pertanggungan ini disebut dengan pertanggungan kerugian.

Disamping pertanggungan kerugian ini juga dikenal dengan pertanggungan dimana pergantian kerugian yang diberikan oleh penanggung sebenarnya tidak dapat dikatakan sebagai suatu ganti rugi oleh karena itu orang yang menerima ganti rugi yang sungguh-sungguh sesuai dengan 
kerugian yang dideritanya. Ganti rugi yang diterima itu sebenarnya adalah sejumlah uang tertentu yang sudah disepakati oleh para pihak. Pertanggungan jenis ini dikenal dengan istilah pertanggungan sejumlah uang atau pertanggungan jumlah atau pertanggungan orang (jiwa).

Perkembangan asuransi pada prinsipnya berpangkal pada 2 (dua) jenis asuransi yaitu Asuransi Kerugian dan Asuransi Jiwa, namun akibat perkembangan dan kebutuhan atau perlindungan akibat suatu peristiwa tidak tentu, berkembanglah berbagai jenis asuransi seperti, asuransi beasiswa, asuransi kredit dan lain-lain.

Dalam hubungan perekonomian dan perdagangan perlu modal usaha, baik usaha kecil, menengah maupun usaha besar, merupakan hal yang sangat penting sebab tanpa modal yang cukup dunia usaha akan sulit untuk berkembang, salah satu upaya untuk memenuhi kebutuhan akan modal usaha adalah dapat melakukan pinjaman atau mengajukan ikatan kredit kepada Bank dan memang banyak bank-bank, baik bank pemerintah maupun bank swasta memberikan pelayanan produksinya berupa kredit dengan berbagai macam variatifnya, hal ini tidak lain untuk memberikan daya tarik kepada masyarakat agar menggunakan produk yang ditawarkannya.

Ikatan kredit yang dilakukan dengan bank, dapat dilakukan tidak hanya oleh seorang debitur saja tetapi dapat juga dilakukan oleh beberapa debitur yang mengikatkan diri masing-masing untuk melakukan ikatan kredit secara tanggung renteng, dimana setiap orang mempunyai kewajiban untuk membayar angsuran kreditnya sesuai dengan jumlah angsuran yang tertulis di dalam Surat Pengakuan Hutang (SPH).

Dalam perkembangannya kredit yang diberikan oleh perbankan untuk menghindari peristiwa tertentu, seperti si debitur (yang berutang) meninggal dunia, banyaknya bank selain memberikan layanan kredit juga sekaligus memberikan layanan jasa asuransi jiwa sehingga apabila debitur meninggal dunia, kredit yang masih berjalan akan ditanggung pembayarannya oleh asuransi tersebut, dengan demikian pembayaran angsuran kredit tidak diwariskan kepada ahli warisnya.

Perjanjian Pertanggungan yang diberikan bagi debitur, dilakukan bersamaan dalam pernyataan ikatan kredit, ketiga orang tersebut mengadakan ikatan kredit dengan bank, didalamnya pula telah dilakukan perjanjian 
pertanggungan, sehingga debitur tidak perlu lagi mengadakan perjanjian pertanggungan yang baru. Para nasabahnya juga telah mengasuransikan peminjaman kredit tersebut dengan kemungkinan adanya peristiwa tidak tentu yang mengakibatkan nasabah meninggal dunia, sehingga tidak bisa lagi membayar angsuran kreditnya. Perusahaan asuransi dapat memberikan perlindungan asuransi bagi para nasabahnya yang meminjam kredit, dengan menjalin kerjasama antara pihak bank dengan pihak perusahaan asuransi.

Di dalam ikatan kredit yang dilakukan secara tanggung renteng tidak semua yang mengikatkan diri di dalam Surat Pengakuan Hutang itu mendapatkan Jaminan Asuransi, dalam hal ini hanya orang yang tercatat pertama saja yang memperoleh jaminan asuransi sedangkan yang lainnya tidak memperoleh jaminan asuransi, sehingga apabila yang pertama meninggal dunia sebelum kreditnya habis dengan sendirinya, maka kredit tersebut akan dilunasi oleh pihak asuransi, tetapi jika yang meninggal yang lainnya maka kredit harus tetap dibiayai oleh mereka yang mengikatkan diri dengan Surat Pengakuan Hutang tersebut.

Penanggung akan memberikan perlindungan terhadap tertanggung apabila terjadi peristiwa yang tidak tentu itu (evenement) seperti kecelakaan, kebakaran, sakit, kematian dan lain-lain sehingga menimbulkan kerugian bagi Tertanggung.

Asuransi merupakan suatu persetujuan dengan mana satu pihak penanggung mengikatkan diri pada yang lain, tertanggung untuk mengganti kerugian yang diderita tertanggung karena terjadi suatu peristiwa yang telah ditunjuk dan yang belum tentu dimana tertanggung berjanji untuk membayar premi. Untuk memperoleh perlindungan asuransi maka seseorang harus mengadakan perjanjian pertanggungan dengan perusahaan asuransi, yang akan memberikan jaminan perlindungan tersebut berdasarkan Pasal 246 KUHD yaitu : Asuransi atau pertanggungan adalah suatu perjanjian, dimana seorang Penanggung mengikatkan diri pada seorang Tertanggung dengan menerima suatu premi, untuk memberikan penggantian kepadanya karena suatu kerugian, kerusakan atau kehilangan yang diharapkan keuntungan yang merugikan akan dideritanya karena suatu peristiwa yang tidak tentu.

Pada pokoknya jenis asuransi hanya 2 (dua) yaitu Asuransi Kerugian dan Asuransi Jiwa. Asuransi Kerugian yang menjadi objeknya adalah benda 
dimana akibat benda tersebut hilang atau musnah yang mengakibatkan timbulnya kerugian bagi si pemilik benda tersebut. Untuk mengganti resiko kerugian akibat musnahnya benda tersebut, maka barang atau benda itu diasuransikan, sehingga apabila hilang atau musnah maka asuransi akan menanggung ganti kerugian.

Asuransi Jiwa yang menjadi objek asuransinya adalah jiwa manusia (jiwa dari si tertanggung) baik karena kecelakaan, sakit maupun meninggal dunia, dengan adanya asuransi tersebut apabila terjadi suatu peristiwa yang tidak tentu maka segala biaya yang ditimbulkan akan ditanggung oleh asuransi.

Ikatan kredit dengan Bank dapat dilakukan oleh beberapa orang debitur yang masing-masing saling menanggung untuk membayar hutang secara tanggung renteng.

Dalam Pasal 1278 KUH Perdata dinyatakan suatu perikatan tanggung menanggung atau perikatan tanggung renteng terjadi antara beberapa orang berpiutang, jika di dalam persetujuan secara tegas kepada masing-masing diberikan hak untuk menuntut pemenuhan seluruh utang sedangkan pembayaran yang dilakukan kepada salah satu membebaskan orang yang berutang meskipun menurut sifatnya dapat dipecah dan dibagi diantara beberapa orang yang berpiutang tadi.

Berdasarkan ketentuan Pasal 1278 KUH Perdata tersebut, beberapa debitur dapat mengikatkan diri dalam suatu perikatan kredit, yang setiap orang melakukan pembayaran dan akan membebaskan orang lain dari kewajibannya secara tanggung renteng yang setiap orang yang melakukan kata kredit dengan pihak Bank, tidak akan terlepas dari suatu peristiwa yang tidak tentu (evenement) seperti kematian yang mengakibatkan tidak dapat melunasi kewajiban membayar hutangnya, untuk menghindari hal seperti itu Bank telah mengasuransikan para nasabah pemegang kredit, sehingga apabila pemegang kredit tersebut meninggal dunia sebelum masa jangka waktunya habis, asuransi akan menanggung semua kewajiban hutang kepada Bank.

Dalam latar pemikiran di atas terdapat permasalahan : Bagaimanakah pelaksanaan asuransi terhadap debitur secara tanggung renteng dihubungkan dengan Pasal 1278 KUH Perdata? 
Penelitian ini bertujuan untuk menganalisis tentang pelaksanaan asuransi terhadap debitur secara tanggung renteng berdasarkan pasal 1278 KUH Perdata.

Adapun kegunaannya secara teoritis dapat memberikan manfaat bagi perkembangan ilmu pengetahuan khususnya Hukum Asuransi, Hukum Perikatan dan Hukum Keperdataan pada umumnya.

\section{Tinjauan Pustaka}

\subsection{Pengertian Asuransi}

Asuransi dalam Bahasa Belanda adalah "Verzekering" yang berarti "Pertanggungan" sedangkan berdasarkan pengertian yuridiksinya yaitu dalam Pasal $246 \mathrm{KUH}$ Dagang yaitu Asuransi atau pertanggungan aalah suatu perjanjian dengan mana seorang penanggung mengikatkan diri pada seorang tertanggung dengan menerima suatu premi untuk memberikan penggantian kepadanya karena suatu premi untuk memberikan pergantian kepadanya karena suatu kerugian, kerusakan atau kehilangan keuntungan yang diharapkan yang mungkin akan dideritanya karena suatu peristiwa yang tidak tentu.

Sedangkan pengertian Asuransi menurut Molengraaff berbunyi : Asuransi kerugian ialah persetujuan dimana suatu pihak penanggung mengikatkan diri terhadap yang lain, tertanggung untuk mengganti kerugian yang dapat diderita oleh tertanggung. Karena terjadinya suatu peristiwa yang telah ditunjuk, dengan yang belum tentu serta kebetulan, dengan mana pula tertanggung berjanji untuk membayar premi. $(\mathrm{H}$. Mashudi dan Moch. Chaidir Ali; 1995 : hal. 3).

\subsection{Sumber Hukum Asuransi}

Menurut Wiryono Prodjodikoro Asuransi termasuk golongan persetujuan untung-untungan (kansovereenkomst), menurut Pasal 1774 $\mathrm{KUH}$ Perdata yaitu suatu perjanjian untung-untungan adalah suatu perbuatan yang hasilnya mengenai untung ruginya, baik bagi semua pihak maupun bagi sementara pihak, bergantung pada suatu kejadian yang belum tentu. Dengan demikian adalah perjanjian pertanggungan, bunga cagak hidup, perjudian dan pertaruhan. 
Antara asuransi, bunga cagak hidup dan perjudian atau pertaruhan mempunyai faedah yang sama, akan tetapi diantara ketiganya terdapat beberapa perbedaan.

a. Objek Asuransi

Objek dalam suatu perjanjian dapat diartikan sebagai hal diperlukan oleh subjek, suatu hal penting dalam tujuan membentuk suatu perjanjian sehingga hal yang diwajibkan kepada pihak yang berkewajiban terhadap mana pihak yang berhak, yang mempunyai hak adalah merupakan objek dalam hubungan hukum mengenai perjanjian (Djoko Prakoso, 1997 : 82).

Benda Asuransi adalah benda yang menjadi objek perjanjian asuransi, Benda Asuransi adalah harta kekayaan yang mempunyai nilai jual ekonomi, yang dihargai dengan sejumlah uang. Benda Asuransi selalu berwujud misalnya gedung, pertokoan, rumah, kapal, benda asuransi selalu diancam oleh bahaya atau peristiwa yang terjadinya tidak pasti. Ancaman bahaya mungkin terjadi yang mengakibatkan benda asuransi dapat rusak, hilang, musnah atau berkurang nilainya. (Abdul Kadir Muhamad, $2002:$ 87).

b. Asuransi Dengan Bunga Cagak Hidup (Lifferente)

1. Asuransi

a. Asuransi mengumpulkan premi untuk membayar sejumlah uang sekaligus bila Onzeker Voorval menjadi pasti.

b. Terjadi Onzeker Voorval menjadi pasti makamewajibkan asuradur memberi prestasi, inisialnya dalam asuransi jiwa kematian seseorang tentu mewajibkan asuransi untuk membayar sejumlah uang.

c. Inisialnya pada asuransi jiwa apabila kematian seseorang tertentu lebih cepat terjadinya, maka ini merupakan kerugian bagi asuransi karena ia harus membayar prestasi penuh.

d. Jika ada perubahan nilai uang (inflasi inisialnya) tidaklah menimbulkan kerugian bagi asuransi maupun bagi pihak tertanggung $(\mathrm{H}$. Mashudi, Moh. Chaidir, 1995 : 44). 
2. Bunga Cagak Hidup (Lissfreni)

a. Debitur menerima uang pokok sekaligus untuk membayar presasi secara berangsur-angsur.

b. Kematian seseorang tertentu (badan) membebaskan debitur dari kewajiban membayar bunga (prestasi).

3. Asuransi dengan Perjudian dan Pertaruhan (Spel en Wedenschap)

a. Para pihak sejak semula sudah mempunyai kepentingan (Insurable Interest) terhadap peristiwa tertentu, kewajiban mempunyai kepentingan ini ditentukan dalam Pasal $250 \mathrm{KUH}$ Dagang. Jika tidak ada kewajiban dan semula asuransi tidak usah mengganti kerugian.

b. Pembayaran ganti rugi adalah sebagai pembayaran penggantian berhubung pihak tertanggung telah menderita kerugian dengan demikian tertanggung hanya menerima sejumlah kerugian yang diterima.

c. Perjanjian merupakan Civil Verbintenis yaitu bahwa pelaksanaan prestasinya dapat dilakukan melalui tuntutan hukum di muka hakim (Jika ada schuld dan haftung).

d. Civiel Verbinteniis karena pembayaran uang asuransi kepada tertanggung bukanlah penambahan atas kekayaannya melainkan untuk menutup suatu kerugian atau resiko yang diderita sebagai akibat dari suatu peristiwa tertentu yang semula belum dapat ditentukan akan terjadi atau tidak.

e. Sebelum terjadi ganti kerugian, tertanggung telah mengeluarkan uang (premi prestasi) lebih dulu pada asuradur.

f. Disamping dapat diadakan tuntutan perdata juga dapat dilakukan pidana karena penipuan $(\mathrm{H}$. Mashudi dan Moch. Caidir : 1995, 48).

\subsection{Syarat Syah Perjanjian Asuransi}

Karena asuransi merupakan perjanjian maka dengan demikian berlaku ketentuan-ketentuan hukum perjanjian. Agar suatu perjanjian 
dibuat secara sah sehingga akan mengikat mereka yang membuatnya, menurut Pasal 1320 KUH Perdata harus memenuhi empat syarat yaitu :

a. Sepakat para pihak yang membuat perjanjian

Pihak-pihak yang mengadakan pertanggungan harus ada persetujuan kehendak (consensus toestemmeing of Ininds) artinya kedua belah pihak menyetujui benda objek perjanjian atas objek yang dipertanggungjawabkan antara tertanggung dan penanggung (Abdulkadir, Muhammad; 1994 : 11).

b. Kecakapan Untuk Membuat Perjanjian

Dimana kedua belah pihak yang mengadakan pertanggungan harus wenang melakukan perbuatan hukum (bekwaam) artinya kedua belah pihak harus sudah dewasa tidak di bawah pengampuan (curatele) tidak dalam sakit ingatan, tidak dalam keadaan pailit.

Kedua belah pihak dapat berupa badan hukum tetapi pihak tertanggung dapat berupa badan hukum atau manusia pribadi, sedangkan pihak penanggung selalu badan hukum yang menjalankan usaha perasuransian seperti yang diatur dalam Pasal 7 ayat (1) Undang-undang Nomor 2 Tahun 1992 (Abdul Kadir, Muhammad; 1994 : 22).

c. Suatu Hal Tertentu

Mengenai objeknya dapat ditentukan sehingga bila terjadi perselisihan dapat ditetapkan hak dan kewajiban masing-masing yaitu :

a) Essensialia $\quad$.... syarat yang menentukan perjanjian.

b) Naturalia $\quad$ :... bagian merupakan sifat bawaan.

c) Accedentalia : ... merupakan sifat yang melekat pada perjanjian (Mariam Darus Badruzaman; 2001 : 99).

d. Klausula Yang Halal

Yaitu tidak bertentangan dengan Undang-undang, Ketertiban dan Kesusilaan.

Tujuan yang hendak dicapai dalam pertanggungan adalah peralihan resiko atas objek pertanggungan yang diimbangi dalam pembayaran premi, jadi kedua belah pihak yang berprestasi, tertanggung membayar premi, penanggung menerima peralihan 
resiko atas obyek pertanggungan jika premi dibayar, resiko beralih. Jika premi tidak dibayar resiko tidak beralih (Abdul Kadir, Muhammad, 1995 : 23).

Ketentuan dari Pasal 1320 KUH Perdata berlaku juga pada perjanjian asuransi yang merupakan syarat umum disamping syarat khusus antara lain :

a. Asas Kepentingan yang dapat diasuransikan (Insurable Interest Principle).

Kepentingan yang dapat diasumsikan merupakan asas utama ilmu perjanjian asuransi/ pertanggungan. Setiap yang bermaksud mengadakan perjanjian asuransi, harus mempunyai kepentingan yang dapat diasuransikan. Maksudnya adalah bahwa pihak Tertanggung mempunyai keterlibatan sedemikian rupa dengan akibat dari suatu peristiwa yang belum pasti terjadinya dan yang bersangkutan menjadi menderita kerugian.

Oleh karena itu guna mendeteksi apakah seseorang mempunyai kepentingan atau tidak, dapat diketahui atas pertanyaanpertanyaan sebagai berikut :

1. Sejauhmanakah keterkaitan tertanggung terhadap benda/ objek perjanjian asuransi atas terjadinya suatu peristiwa yang diperjanjikan ?

2. Apakah peristiwa yang terjadi menyebabkan kerugian terhadap tertanggung?

Menurut Dourhout Mess pengertian kepentingan merupakan suatu faktor ekonomi yang murni sehingga sangat sulit untuk diberi batasan menurut hukum batasan "kepentingan", di dalam asuransi atau pertanggungan dapat dimulai dari seseorang dapat dianggap mempunyai kepentingan di dalam perjanjian asuransi apabila tersebut menderita kerugian yang bersifat kerugian ekonomi, sehingga kepentingan diartikan sebagai "keterlibatan kerugian keuangan, karena suatu peristiwa yang belum pasti”.

b. Asas Kejujuran yang sempurna (Utmost Goodfait Principle)

Istilah kejujuran yang sempurna dalam perjanjian asuransi yaitu itikad baik yang sebaik-baiknya. Asas ini harus dipenuhi oleh 
para pihak yang mengadakan perjanjian, tidak dipenuhinya asas ini pada saat akan menutup suatu perjanjian akan menyebabkan adanya cacat kehendak yang diatur oleh Pasal 1320-1329 KUH Perdata. Bagaimanapun itikad baik merupakan satu dasar utama dan kepercayaan yang melandasi setiap perjanjian pada dasarnya tidak melindungi pihak yang beritikad buruk.

c. Asas Indeminitas (Indemnity Principle)

Asas Ideminitas adalah asas utama dalam perjanjian asuransi, karena merupakan asas yang mendasari mekanisme kerja dan memberikan arah tujuan dan perjanjian asuransi itu sendiri (khusus untuk asuransi kerugian). Perjanjian asuransi mempunyai tujuan utama dan spesifik adalah untuk memberi suatu ganti kerugian kepada pihak tertanggung oleh pihak penanggung. Pengertian kerugian itu tidak boleh menyebabkan posisi kerugian pihak tertanggung menjadi lebih diuntungkan dari posisi sebelum menderita kerugian.

Asas Indeminitas adalah sebagai landasan dasar sebagaimana dimaksud dalam Pasal $246 \mathrm{KUH}$ Dagang yang pada hakekatnya mengandung dua aspek yaitu :

a) Hubungan dengan tujuan perjanjian, harus ditujukan kepada ganti kerugian, bahwa pihak tertanggung karena pembayaran ganti rugi jelas akan menduduki posisi yang lebih menguntungkan. Jadi bila terdapat klausula yang bertentangan dengan tujuan ini menyebabkan batalnya perjanjian.

b) Berhubungan dengan pelaksanaan perjanjian asuransi sebagai keseluruhan yang sah (Sri Rejeki Hartono, 1991 : 100-101).

d. Asas Suborgasi (Subrogation Principle)

Asas ini secara tegas diatur dalam Pasal $284 \mathrm{KUH}$ Dagang yang berbunyi : "Seorang penanggung yang telah membayar kerugian sesuatu barang yang dipertanggungkan, menggantikan si tertanggung dalam segala hak yang diperolehnya terhadap orangorang ketiga berhubung dengan menerbitkan kerugian tersebut, dan Si Tertanggung adalah bertanggung jawab untuk setiap perbuatan 
yang dapat merugikan hak si penanggung terhadap orang-orang ketiga itu".

Subrogan dalam asuransi adalah Subrogan berdasarkan Undang-undang. Oleh karena itu Subrogan hanya dapat ditegaskan apabila memenuhi syarat-syarat sebagai berikut :

1. Apabila tertanggung disamping mempunyai hak terhadap penanggung masih mempunyai hak-hak terhadap pihak ketiga.

2. Hak tersebut timbul karena terjadinya suatu kerugian. (Sri Rejeki Hartono, 1991 : 107).

\subsection{Proses Perjanjian Asuransi}

Menurut ketentuan Pasal 257 ayat (1) KUH Dagang perjanjian pertanggungan terjadi seketika setelah tercapai persetujuan kehendak (consensus) antara tertanggung dan penanggung hak dan kewajiban timbal balik sejak saat itu bahkan sebelum polis ditandatangani tertanggung tersebut harus dibuat secara tertulis dan lahir suatu akta yang disebut polis. (Abdul Kadir Muhamad, 1995 : 24).

Untuk membuktikan bahwa telah terjadi kata sepakat antara dua belah pihak, yang mengharuskan pembuktian dengan alat bukti tertulis berupa akta yang disebut polis.

Saat terjadi pertanggungan sdah dapat dibuktikan kemudian timbul perselisihan tetapi janji-janji dan syarat-syarat khusus maka dapat dibuktikan dengan alat bukti (Abdul Kadir Muhamad, 1995 : 26) yaitu pelaksanaan hak dan kewajiban kedua belah pihak, seperti penyebab kerugian, sifat kerugian yang menjadi beban penanggung, pembayar oleh Tertanggung.

Pertanggung untuk kepentingan pihak ketiga dapat diadakan dan dicari :

a. Pemberian Kuasa Umum (General Authorization).

b. Pemberian Kuasa Khusus (Special Authorization).

c. Tanpa Kuasa (Without Authorization)

Pertanggungan untuk kepentingan pihak ketiga itu sendiri tanpa kuasa diatur dalam Pasal 266 KUH Dagang yaitu jika terjadi pertanggungan untuk kepentingan pihak ketiga tanpa pemberian kuasa 
dan tanpa diketahui pihak ketiga itu, pertanggungan itu batal, yaitu jika terhadap kepentingan yang sama diadakan pertanggungan pula oleh atau unit pihak ketiga sebelum dia mengetahui bahwa orang lain telah mengadakan pertanggungan untuk kepentingannya (Emy Pangaribuan Simanjuntak, $1990: 23)$.

\subsection{Pembuktian Terhadap Perjanjian Asuransi}

Menurut ketentuan Pasal 255 KUH Dagang Perjanjian Asuransi atau pertanggungan harus dibuat secara tertulis dalam suatu akta yang disebut polis. Polis berfungsi sebagai alat bukti bahwa telah terjadi pertanggungan dengan penanggung. Dalam polis dicantumkan semua ketentuan dan mengenai pertanggungan yang telah dibuat (Abdul Kadir Muhamad, 1995 : 27).

Sifat khusus dari folis adalah mengenai hal-hal itu tidak dimuat maka persetujuan asuransi itu batal dengan kata lain sifat khusus dari polis yaitu sifat istimewa sebagai alat bukti yang sempurna (Vollegig Bewijs) (Wirjono Prodjodikoro, 1981 : 29).

\section{Kesimpulan}

1. Dalam pelaksanaan asuransi terhadap debitur secara tanggung renteng dihubungkan dengan Pasal $1278 \mathrm{KUH}$ Perdata tidak sepenuhnya diterapkan karena terkait dengan perjanjian asuransi hanyalah pihak pemakai kredit (debitur) ke-1 (satu) yang riil adalah pihak pemakai kredit (debitur) ke-2 (dua) dan Surat Pengakuan Hutang (SPH) padahal dalam kenyataannya pemakai.

2. Kredit yang riil adalah pihak debitur ke-3 (tiga) dan debitur ke-4 (empat) dan tidak terikat secara langsung dalam perjanjian kredit serta tidak diasuransikan secara tanggung renteng kepada pihak krediturnya. Akan tetapi pihak ke-2 (dua) meninggal dunia maka debitur ke-1 (satu) dalam perjanjian kredit atas hutangnya debitur tidak lunas, melainkan utangutangnya terus dibayar oleh atau atas kekayaan milik debitur. 


\section{Daftar Pustaka}

Gunawan Widjaya, Kartini Mulyadi, Seri Hukum Perikatan Pertanggungan Utang dan Perikatan Tanggung Menanggung, PT Raja Grafindo Persada, Jakarta, 2002.

H. Mashudi, Hukum Asuransi, PT MAndar maju, Bandung, 1995.

Muhammad Abdul KAdir, Pengertian Hukum Pertanggungan, Citra Aditya, Bandung, 1994.

Prodjodikoro, Wiryono, Hukum Asuransi di Indonesia, Intermasa, Jakarta, 1994.

Simanjuntak, Pangaribuan Emmy, Hukum Pertanggungan, Seksi Hukum Dagang, Fakultas Hukum (UGM), Yogyakarta, 1990.

Subekti, R. Aneka Perjanjian, Citra Aditya, Bandung, 1995.

Kitab Undang-Undang Hukum Perdata

Kitab Undang-Undang Hukum Dagang 